\title{
PENYALAHGUNAAN JABATAN WALI KOTA BEKASI DALAM ANGGARAN (Studi Kasus Putusan Nomor 2547 K/Pid.sus/2011)
}

\author{
Oleh : \\ Sugeng Riyanto \\ Program Magister Hukum Universitas Krisnadwipayana \\ J1. Raya Jatiwaringin, RT. 03 / RW. 04, Jatiwaringin, Pondok Gede, Jaticempaka, Kec. Pondokgede \\ Kota Bekasi, Jawa Barat 13077 \\ Email : sugengunsuryahukum@yahoo.co.id
}

\begin{abstract}
Abstrak
Korupsi yang terjadi di Indonesia saat ini, sudah dalam posisi yang sangat parah dan begitu mengakar dalam setiap sendi kehidupan. Perkembangan praktek korupsi dari tahun ke tahun semakin meningkat. Salah satu praktek korupsi yang dilakukan oleh Walikota Bekasi Mochtar Mohamad yang telah menghabiskan anggaran sebesar 1,6, serta mencoba menyuap anggaran pendidikan berupa upeti dan anggaran diminta untuk membayar utang pribadinya sebesar 639 jt. Metode penelitian yang digunakan adalah yuridis normatif yaitu penelitian yang menekankan pada penggunaan norma-norma hokum secara tertulis serta didukung dengan hasil wawancara dengan narasumber dan informan. Walikota Bekasi terjerat hukum dengan melanggar korupsi dan telah berlawanan dengan spirit dari undang-undang no. 28 tahun 1999 tentang penyelenggaraan Negara norma yang mengajak masyarakat untuk mencapai cita-cita Negara namun sebagai Negara hukum seluruh masyarakat Indonesia tidak bisa lepas dari jeratan hukum sehingga Walikota Bekasi mendapat hukuman sesuai dengan Putusan Nomor 2547 K/Pid.sus/2011.
\end{abstract}

Kata Kunci : Penyalahgunaan Jabatan, Korupsi

\section{PENDAHULUAN}

Korupsi yang terjadi di Indonesia saat ini, sudah dalam posisi yang sangat parah dan begitu mengakar dalam setiap sendi kehidupan. Perkembangan praktek korupsi dari tahun ke tahun semakin meningkat, baik dari kuantitas atau jumlah kerugian keuangan negara maupun dari segi kualitas yang semakin sistematis, canggih serta lingkupnya sudah meluas dalam seluruh aspek masyarakat. Meningkatnya tindak pidana korupsi yang tidak terkendali akan membawa bencana tidak saja terhadap kehidupan perekonomian nasional tetapi juga pada kehidupan berbangsa dan bernegara pada umumnya. Maraknya kasus tindak pidana korupsi di Indonesia, tidak lagi mengenal batas-batas siapa, mengapa, dan bagaimana. Tidak hanya pemangku jabatan dan kepentingan saja yang melakukan tindak pidana korupsi, baik di sektor publik maupun privat, tetapi tindak pidana korupsi sudah menjadi suatu fenomena.

Penyelenggaraan negara yang bersih menjadi penting dan sangat diperlukan untuk menghindari praktek-praktek korupsi yang tidak saja melibatkan pejabat 
bersangkutan, tetapi juga oleh keluarga dan kroninya, yang apabila dibiarkan, maka rakyat Indonesia akan berada dalam posisi yang sangat dirugikan. Menurut Nyoman ${ }^{1}$ Serikat Putra Jaya menyebutkan bahwa tindak pidana korupsi tidak hanya dilakukan oleh penyelenggara negara, antar penyelenggara negara, melainkan juga penyelenggara negara dengan pihak lain seperti keluarga, kroni dan para pengusaha, sehingga merusak sendi-sendi kehidupan bermasyarakat, berbangsa, dan bernegara, serta membahayakan eksistensi negara.

Tindak pidana korupsi merupakan perbuatan yang bukan saja dapat merugikan keuangan negara akan tetapi juga dapat menimbulkan kerugiankerugian pada perekonomian rakyat. Barda Nawawi Arief²berpendapat bahwa, tindak pidana korupsi merupakan perbuatan yang sangat tercela, terkutuk dan sangat dibenci oleh sebagian besar masyarakat; tidak hanya oleh masyarakat dan bangsa Indonesia tetapi juga oleh masyarakat bangsa-bangsa di dunia.2 Perkembangan korupsi di Indonesia masih tergolong tinggi, sedangkan pemberantasannya masih sangat lamban.

Romli Atmasasmita menyatakan bahwa korupsi di Indonesia sudah merupakan virus flu yang menyebar ke seluruh tubuh pemerintahan sejak tahun 1960-an langkah-langkah pemberantasannya pun masih tersendatsendat sampai sekarang. Selanjutnya, dikatakan bahwa korupsi berkaitan pula dengan kekuasaan karena dengan kekuasaan itu penguasa dapat

\footnotetext{
${ }^{1}$ Nyoman Serikat Putra Jaya. 2005. Tindak Pidana Korupsi, Kolusi dan Nepotisme di Indonesia, Semarang Badan Penertib : UNDIP Hal 37

2 Barda Nawawi Arief kebijakan legislatif dalam penanggulangan kejahatan dengan pidana rejah, Semarang, Badan Penerbit UNDIP 2000 No, 17
}

menyalahgunakan kekuasaannya untuk kepentingan pribadi, keluarga dan kroninya.

Di Indonesia adanya kerugian keuangan negara atau perekonomian negara menjadi unsur dari delik korupsi sebagaimana diatur dalam Pasal 2 dan Pasal 3 Undang-Undang Nomor 31 Tahun 1999 jo Undang-Undang Nomor 20 Tahun 2001 tentang Pemberantasan Tindak Pidana Korupsi (UU Tipikor).

Pasal 2 UU Tipikor berbunyi: "Setiap orang yang secara melawan hukum melakukan perbuatan memperkaya diri sendiri atau orang lain atau suatu korporasi yang dapat merugikan keuangan negara atau perekonomian negara, dipidana dengan pidana penjara seumur hidup atau pidana penjara paling singkat 4 (empat) tahun dan paling lama 20 (duapuluh) tahun dan denda paling sedikit RP.200.000.000,00 (dua ratus juta rupiah) dan paling banyak Rp.1.000.000.000,00 (satu miliar rupiah)".

Seperti yang terjadi di Bekasi, Jawa Barat dimana mantan Walikota Muchtar Muhammad terbukti melakukan penyuapan kepada anggota Dewan Perakilan Rakyat. Modusnya, ia meminta pimpinan satuan kerja di pemerintah Kota Bekasi untuk menyisihkan dua persen uang proyek. Terkumpulah uang $\mathrm{Rp} 4,5$ miliar. Atas perintah Muchtar, Rp 4 miliar itu diberikan kepada anggota dewan agar anggaran pendapatan dan belanja daerah Kota Bekasi tahun 2010 segera disetujui. Kasus kedua, dia terbukti menerima upeti proyek di Kota Bekasi. Misalnya proyek di Dinas Kesehatan dan Pendidikan. Mochtar memakai uang Rp 639 juta dari pos anggaran makanan dan minuman. Uang itu untuk membayar utangnya ke sebuah bank (Majalah Tempo, 25/03/12.

Dari catatan kasus Muchtar, begitu kentalnya politik suap. Sehingga wajar bila Deputi Bidang Informasi dan Data KPK 
Penyalahgunaan Jabatan Wali Kota Bekasi Dalam Anggaran (Studi Kasus Putusan Nomor 2547 K/Pid.Sus/2011)

DRM Syamsya Ardisasmita DEA menyebutkan, Transparency International, sebuah organisasi non-pemerintah yang giat mendorong pemberantasan korupsi, menempatkan Indonesia sebagai salah satu negara paling korup di dunia. Berdasarkan hasil surveynya, Indonesia nilai Indeks Persepsi Korupsinya (IPK) pada tahun 2005 adalah 2,2 (nilai nol sangat korup dan nilai 10 sangat bersih. Indonesia jatuh pada urutan ke-137 dari 159 negara yang disurvei. IPK ini merupakan hasil survei tahunan yang mencerminkan persepsi masyarakat internasional maupun nasional (mayoritas pengusaha) terhadap tingkat korupsi di suatu negara.

Korupsi sudah begitu meluas dan memprihatinkan, dan sulit ditangulangi. Tindak pidana korupsi di Indonesia sudah begitu parah dan meluas dalam kehidupan masyarakat dan sangat memprihatinkan. Perkembangan terus meningkat dari tahun ke tahun, baik dari jumlah kasus yang terjadi maupun dari jumlah kerugian keuangan negara serta dari mudus operandi dan kualitas tindak pidana yang dilakukan semakin sistematis, serta lingkupnya memasuki seluruh lapisan kehidupan. Tindak pidana korupsi terjadi pada lembaga-lembaga formal kenegaraan seperti eksekutif, yudikatif dan legislatif. Uraian-uraian diatas menunjukan betapa korupsi sangat merugikan tidak hanya pada negara tapi juga pada hak-hak rakyat khusunya hak untuk mendapatkan keadilan dan kesejahteraan.

\section{TINJAUAN PUSTAKA}

1. Tindak Pidana (Moljatno: 1985): adalah perbuatan yang dilarang oleh suatu aturan hukum, larangan mana disertai ancaman (sanksi) yang berupa pidana tertentu, bagi barang siapa yang melanggar aturan tersebut.
2. Penyalahgunaan Jabatan (UU No. 31

Tahun 1999 pasal 3):

Menyalahgunakan kewenangan, sarana atau kesempatan yang ada padanya karena jabatan atau kedudukan adalah peristilahan yang digunakan pembentuk Undang-undang untuk menggambarkan sifat melawan hukum tindak pidana korupsi

3. Kewenangan merupakan hak menggunakan wewenang yang dimiliki seorang pejabat atau institusi menurut ketentuan yang berlaku, dengan demikian kewenangan juga menyangkut kompetensi tindakan hukum yang dapat dilakukan menurut kaedah-kaedah formal, jadi kewenangan merupakan kekuasaan formal yang dimiliki oleh pejabat atau institusi

4. Keadilan (Aristoteles) berpendapat bahwa tujuan hukum itu semata-mata untuk mewujudkan keadilan. Keadilan di sini adalah ius suum quique tribuere, yang artinya memberikan kepada setiap orang apa yang menjadi bagian atau haknya. Formulasinya tentang keadilan bertumpu pada tiga sari hukum alam yang dianggapnya sebagai prinsip keadilan utama yaitu honestevivere, alterium nonlaidere, suum quique tribuere (hidup secara terhormat, tidak mengganggu orang lain, dan memberi kepada tiap orang)

5. Perlindungan hukum diartikan sebagai suatu bentuk tindakan atau perbuatan hukum pemerintah yang diberikan kepada subjek hukum sesuai dengan hak dan kewajibannya yang dilaksanakan berdasarkan hukum positif di Indonesia. Perlindungan hukum timbul karena adanya suatu hubungan hukum. 


\section{METODE PENELITIAN}

Pada penelitian ini penulis menggunakan yuridis normatif yaitu penelitian yang menekankan pada penggunaan norma-norma hukum secara tertulis serta didukung dengan hasil wawancara dengan narasumber dan informan (Dian, 2010), Sedangkan tipe penelitian Penelitian ini bersifat deskriptif karena menggambarkan peraturan perundang-undangan yang beraku dan dikaitkan dengan teori - teori hukum yang berkaitan dengan permasaahan dalam penelitian. Penelitian ini bersifat deskriptif karena menggambarkan peraturan perundang-undangan yang beraku dan dikaitkan dengan teori - teori hukum yang berkaitan dengan permasaahan dalam penelitian.

\section{SUMBER DATA}

Sumber data primer yang digunakan adalah Pancasila dan Pembukaan UUD 1945, Batang Tubuh UUD 1945, UU no. 31 tahun 1999 Tentang Pemberantasan Korupsi, UU no. 20 tahun 2001 ttg Perubahan atas UU no. 31 tahun 1999 ttg Peberantasan Korupsi, sumber data sekunder yang digunakan adalah Hasil hasil penelitian, hasil karya dari kalangan pakar hukum Dokumen lain tentang korupsi, Sedangkan data tersier yang digunakan adalah Kamus umum, Kamus hukum, Surat kabar, Majalah dll.

\section{PEMBAHASAN}

Pelanggaran hukum yaitu telah melakukan penyuapan penyalahgunaan kewenangan, kesempatan, atau sarana hanya berkaitan dengan jabatan atau kedudukan yang melekat pada diri seseorang, yakni pegawai negeri atau pejabat. Penyalahgunaan kewenangan hanya didistribusikan kepada seseorang yang berstatus sebagai pegawai negeri atau pejabat. Selain pegawai negeri atau pejabat tidak bisa dikatakan sebagai melakukan penyalahgunaan kewenangan. Oleh karenanya jika dalam praktik peradilan kasus korupsi ternyata ditemukan bahwa terdakwa didakwa dengan Pasal 3 padahal yang bersangkutan tidak pegawai negeri atau pejabat, jelas disini terdapat konstruksi berpikir yang salah didalam memahami esensi penyalahgunaan kewenangan dan melawan hukum, sebaliknya jika terdakwa berstatus sebagai pegawai negeri atau pejabat tidak sepatutnya jika terdakwa itu didakwa dengan pasal 2 undang-undang korupsi. Dalam praktik peradilan ternyata kesalahan memahami esensi pasal 2 dan pasal 3 undang-undang korupsi ternyata sudah sedemikian rupa sehingga merusak bangunan teori berupa penyalahgunaan kewenangan dan melawan hukum sebagai bestanddeed delict dalam pasal 3 dan Pasal 2 undang-undang tindak pidana korupsi.

Dalam kasus yang dilakukan oleh Terdakwa MOCHTAR MOHAMAD, selaku Walikota Kota Bekasi berdasarkan Keputusan Menteri Dalam Negeri Nomor : 131.32-77 Tahun 2008 tanggal 21 Februari 2008, pada waktu-waktu antara bulan Maret 2009 sampai dengan Desember 2009 atau setidak-tidaknya pada waktu-waktu yang masih dalam tahun 2009 bertempat di Kantor Walikota Bekasi Jalan Ahmad Yani Nomor : 1 Bekasi Jawa Barat, atau setidak-tidaknya di tempattempat lain yang berdasarkan Pasal 35 ayat (1) Undang- Undang Nomor : 46 Tahun 2009 tentang Pengadilan Tindak Pidana Korupsi jo. Pasal 3ayat (1) Keputusan Ketua Mahkamah Agung Republik Indonesia Nomor : 191/KMA/SK/XII/2010 tanggal 01 Desember 2010 tentang Pengoperasian Pengadilan Tindak Pidana Korupsi pada Pengadilan Negeri Bandung, Pengadilan Negeri Semarang, dan Pengadilan Negeri 
Surabaya, yang masih termasuk dalam daerah hukum Pengadilan Tindak Pidana Korupsi di Pengadilan Negeri Bandung yang berwenang, memeriksa dan mengadilinya, dengan tujuan menguntungkan diri sendiri atau orang lain atau suatu korporasi yaitu menguntungkan diri Terdakwa sebesar Rp. 639.000.000,- (enam ratus tiga puluh sembilan juta rupiah), menyalahgunakan kewenangan, kesempatan atau sarana yang ada padanya karena jabatan atau kedudukan yaitu Terdakwa menyalahgunakan kewenangannya selaku Walikota dengan menyisihkan anggaran dari kegiatan yang fiktif atau di Mark-up pada Kegiatan Dialog/Audensi dengan Tokoh-tokoh Masyarakat, Pimpinan / Anggota Organisasi Sosial / Kemasyarakatan Tahun 2009 dengan Mata Anggaran Kegiatan 5.2.2.02.09 dan Mata Anggaran Kegiatan 5.2.2.11.03 Belanja Makanan dan Minuman Tamu yang bersumber dari APBD tahun 2009, yang kemudian dari hasil penyisihan anggaran tersebut dipergunakan oleh Terdakwa untuk mengangsur pinjaman kredit pribadi Terdakwa yang ada di PT. Bank Banten Jabar banten pada tahun 2009 sebesar Rp. 639.000.000,- (enam ratus tiga puluh sembilan juta rupiah), perbuatan Terdakwa tersebut tidak mengindahkan ketentuan : Pasal 28 Undang-Undang Nomor : 32 Tahun 2004 tentang Pemerintahan Daerah yang mengatur bahwa Kepala Daerah dilarang : huruf a : membuat keputusan yang secara khusus memberikan keuntungan bagi diri, yang bertentangan dengan peraturan perundangundangan, huruf $\mathrm{c}$ : melakukan korupsi, kolusi, nepotisme, dan menerima uang, barang dan/atau jasa dari pihak lain yang mempengaruhi keputusan atau tindakan yang akan dilakukannya; huruf e : menyalahgunakan wewenang dan melanggar sumpah/janji jabatannya; jo. bertentangan pula dengan UndangUndang Nomor : 1 Tahun 2004 tentang Perbendaharaan Negara Pasal 3 ayat (3) bahwa "Setiap pejabat dilarang melakukan tindakan yang berakibat pengeluaran atas beban APBN/APBD jika anggaran untuk membiayai pengeluaran tersebut tidak tersedia atau tidak cukup tersedia jo. Peraturan Menteri Dalam Negeri Nomor : 13 Tahun 2006 tentang Pedoman Pengelolaan Keuangan Daerah Pasal 13 ayat (1) bahwa "Setiap pengeluaran belanja atas beban APBD harus didukung bukti yang lengkap dan sah", yang dapat merugikan keuangan Negara Cq. Pemkot Bekasi sebesar Rp. 639.000.000,- (enam ratus tiga puluh Sembilan juta rupiah), sebagaimana Laporan Hasil Perhitungan Kerugian Keuangan Negara dari BPKP Nomor : SR-1145/PW09/5/2011 tanggal 14 Februari 2011 atau setidak-tidaknya sekitar jumlah tersebut.

Perumusan sistem pemidanaan dalam Undang-Undang Pemberantasan Tindak Pidana Korupsi No.31 tahun 1999 Jo. Undang-Undang No.20 tahun 2001 mengatur tentang unsur-unsur dan pengelompokan tindak pidana korupsi, tidak ada rumusan mengenai sistem pemidanaan yang mengatur secara khusus tentang tindak pidana korupsi yang dilakukan oleh pejabat daerah, yang ada hanya kualifikasi delik tindak pidana korupsi yang memenuhi unsur subjeknya yaitu seorang pejabat daerah. Hal ini bisa dilihat dalam: Pasal 3, Pasal 5, Pasal 6, Pasal 8, Pasal 9, Pasal 10, Pasal 11, Pasal 12, Pasal 13, Pasal 15 dan Pasal 22 Undang-Undang Pemberantasan Tindak Pidana Korupsi No.31 tahun 1999 Jo. Undang-Undang No.20 tahun 2001. Hal demikian memang sudah sesuai dengan asasasas pidana yang ada, baik mengenai unsur tindak pidana, unsur perta nggungjawaban pidana, unsur pidana dan pemidanaan, serta cara merumuskan 
sanksi pidana. tetapi mengenai pemidanaannya belum disusun dengan baik oleh tim penyusun undang-undang ini. terkait perumusan pemberian sanksi maksimal khusus dalam hal ini menjadi sorotan.

Karena pemidanaan terkait maksimal khusus bagi pelaku tindak pidana korupsi yang kualifikasi subjeknya adalah pejabat daerah dalam hal ini hanya berupa pidana penjara selama maksimal 20 tahun atau seumur hidup, tidak diperlakukan pidana mati atau alternatif sanksi maksimal khusus lain. Hal demikian sungguh ironis, Mengingat di dalam Pasal 2 Undang-Undang Pemberantasan Tindak Pidana Korupsi No.31 tahun 1999 Jo. Undang-Undang No.20 tahun 2001 yang kualifikasi subjeknya bukan seorang pejabat daerah / penyelenggara Negara diatur tentang pidana mati. Hal demikian justru akan menimbulkan opini negatif tentang pejabat, mengingat dalam tahap formulasi perumusan undang-undang di DPR RI peran pejabat sendiri sangat penting selaku menjalankan fungsinya yaitu sebagai fungsi legislator, hal ini bisa saja diasumsikan bahwa pejabat "melindungi" dirinya sendiri dengan tidak diberlakukannya sanksi maksimal khusus yaitu berupa pemberian sanksi pidana mati atau alternatif sanksi maksimal khusus lain. Padahal seharusnya dalam hal ini pejabat daerah sebagai seorang pemimpin yang selainmemiliki tanggung jawab dari rakyat juga memiliki tanggung jawab moral sebagai seorang pemimpin yang seyogyanya memberikan tindak-tanduk yang baik dalam berperilaku. dan mengingat bahwa salah satu tujuan pemberantasan korupsi adalah demi terselenggaranya pemerintahan yang adil dan bersih sehingga tercipta Pembangunan Nasional yang maju dan berkesinambungan, maka pemberian alternatif sanksi pidana maksimal khusus perlu ditinjau ulang agar menimbulkan efek jera dan tidak muncul pelaku-pelaku baru lagi.

Kebijakan perumusan sistem pemidanaan di masa yang akan datang dalam penanggulangan tindak pidana korupsi yang dilakukan oleh pejabat daerah tentunya dapat mengacu pada kebijakan sistem pemidanaan yang telah dirumuskan oleh Konsep KUHP 2012. Beberapa masalah mengenai sistem pemidanaan yang dirasa masih memerlukan perbaikan dimasa yang akan datang merupakan hal yang perlu diperhatikan dalam rangka menciptakan perundang-undangan yang lebih baik lagi. Dalam konsep KUHP tahun 2012 belum ada perumusan pasal yang terkait dengan sistem pemidanaan yang mengatur secara khusus tentang tindak pidana korupsi yang dilakukan oleh pejabat daerah, yang ada hanya kualifikasi delik tindak pidana korupsi yang memenuhi unsur subjeknya yaitu seorang pejabat daerah. Yang terdapat dalam pasal 663, pasal 664, pasal 666, pasal 669, pasal 670, pasal 674, pasal 688, pasal 691, pasal 696 dan pasal 699, Hal demikian sama dengan aturan dalam Undang-Undang No.31 tahun 1999 Jo. Undang-Undang No.20 tahun 2001. Hanya saja dalam RUU KUHP 2012 ada satu pasal yang sudah mengatur tentang pemberian sanksi maksimal khusus menyangkut tindak pidana korupsi yang dilakukan oleh pejabat daerah, yaitu dalam pasal 699 ayat (2) RUU KUHP dimana pidana mati dapat dijatuhkan bagi pejabat yang melakukan korupsi dalam keadaan tertentu misalnya dalam keadaan bencana alam.

Berdasarkan hal tersebut diatas maka Tiga hakim MA akhirnya sepakat secara bulat mengganjar Mochtar Muhammad dengan penjara selama 6 tahun. Politikus PDIP ini terbukti secara 
sah dan meyakinkan melakukan korupsi Rp 5,5 miliar secara berkelanjutan sesuai Putusan Nomor 2547 K/Pid.Sus/2011.

\section{KESIMPULAN}

1. Penyelenggara Negara mempunyai peran penting dalam mewujudkan citacita perjuangan bangsa. Hal ini secara tegas dinyatakan dalam Penjelasan Undang-Undang Dasar 1945 yang menyatakan bahwa yang sangat penting dalam pemerintahan dan dalam hal hidupnya negara ialah semangat para Penyelenggara Negara dan Pemimpin pemerintahan.

2. Pertanggungjawaban pidana hanya dapat terjadi setelah sebelumnya seseorang melakukan tindak pidana. Pertanggungjawaban pidana dilakukan atas dasar hukum tidak tertulis "tiada pidana tanpa kesalahan". Akan tetapi dalam rancangan KUHP asas ini mendapat penegasan. Pasal 35 rancangan KUHP menentukan, "tidak seorang pun dapat dipidana tanpa kesalahan". Tiada pidana disini berarti tiada pertanggungjawaban.

\section{SARAN}

Sesuai dengan kesimpulan di atas, penulis dapat mengemukakan beberapa saran. Beberapa saran penulis tersebut adalah sebagai berikut :

1. Batasan yang tegas apakah seorang pejabat administrasi negara yang didakwa melakukan tindak pidana korupsi dapat dipertangggungjawabkan adalah kondisi atau faktor objektif di lapangan yaitu apakah ia melakukan tindakan yang sesuai dengan kewenangannya, mengambil kebijakan atau senyatanya bertentangan dengan kewenangan nya berdasarkan peraturan perundang-undangan yang berlaku.

2. Jika ia melakukan tindakan dalam batas kewenangan nya berdasarkan peraturan perundang-undangan yang berlaku, maka semestinya ia tidak dapat dipertanggungjawabkan sebagai pelaku tindak pidana korupsi meskipun telah terjadi kerugian keuangan negara. Dalam hal ini unsur melawan hukum tidak terpenuhi. Walaupun demikian, ia tetap dipertanggungjawabkan secara administrasi.

\section{DAFTAR PUSTAKA}

Adami Chazawi, Pelajaran Hukum Pidana Bagian I, Jakarta, Raja Grafindo Persada,2002.

Abu Rokhmad, 2012, Hukum Progresif pemikiran Satjipto Raharjo dalam Prespektif Teori, PT. Pustaka Rizky Putra, Semarang

Barda Nawawi Arief, 2005, Bunga Rampai Kebijakan Hukum Pidana, Cet ke-3, Citra Bakti, Bandung

Bernard L. Tanya, dkk, 2010, Teori Hukum Strategi Tertib Manusia Lintas Ruang dan Generasi, Gentha Publishing, Yogyakarta

Darji Darmodihardjo dan Shidartha, 2006, Pokok-Pokok Filsafat Hukum, Penerbit PT. Gramedia Pustaka Utama, Jakarta

Dian Puji Sumatupang, Modul Perkuliahan Metode Penelitian, (Jakarta: Program Studi Magister Ilmu Hukum Unkrisna, 2010).

Guse Prayudi, Tindak Pidana Korupsi Dipandang Dalam Berbagai Aspek, (Jakarta: Pustaka Pena,2010) 
Penyalahgunaan Jabatan Wali Kota Bekasi Dalam Anggaran

(Studi Kasus Putusan Nomor 2547 K/Pid.Sus/2011)

Herman Bakir, 2009, Filsafat Hukum Design dan Arsitektur Kesejarahan, Refika Aditama, Bandung

I Ketut Rai Setia Budi, 2014, Vonis Sanksi Pidana tambahan oleh Hakim Berupa Pengembalian Kerugian Keuangan Negara oleh Terpidana Tindak Pidana Korupsi di Pengadilan Negeri Denpasar, Jurnal Magister Hukum Udayana, Volume 6, Denpasar

Indriyanto Seno Adji, Korupsi \& Hukum Pidana, Kantor Pengacara \& Konsultasi Hukum "Prof.Oemar Seno Adji, SH \& Rekan, Jakarta, 2002

Indriyanto Seno Adji, Kebijakan Aparatur Negara \& Hukum Pidana (Jakarta : Diadit Media,2007)

Jamaluddin Kamir, 2013, Politik Hukum Legalistik, Penerbit Imperium, Yogyakarta

Kaelan, Pendidikan Pancasila. (Yogyakarta: Pradigma, 2004)

Komariah Emong Sapardjaja, Ajaran Sifat Melawan Hukum Materiel Dalam Hukum Pidana Indonesia, (Bandung: Alumni, 2002).

Lilik Mulyadi, 2008, Bunga Rampai Hukum Pidana Perspektif Teoritis dan Praktik, PT. Alumni, Bandung

M. Syamsudin, 2012, Konstruksi Baru Budaya Hukum Hakim Berbasis Hukum Progresif, Kencana Prenada Media Group, Jakarta

Munir Fuady, 2011, Teori Negara Hukum Modern Rechtstaat, PT. Refika Aditama, Bandung
Mochtar Kusumaatmadja, Hukum Masyarakat IV Pembinaan Hukum Nasional, Bina Cipta, Bandung, 1976.

Otje S. Soemadiningrat, Filsafat Hukum Perkembangan dan Dinamika Masalah, Refika Aditama, Bandung, 2010.

Satjipto Rahardjo,2000, Hukum dan Masyarakat, Angkasa, Bandung

SF. Marbun, Negara Hukum Indonesia dan Asas-asas Umum Pemerintahan yang layak (AAUPL), (Yogyakarta: Universitas Islam Indonesia, 1998)

Sudarto, 1983, Hukum Pidana dan Perkembangan Masyarakat, Sinar Baru, Bandung

Soerjono Soekanto Dan Sri Mamudji, Penelitian Hukum Normatif, (Jakarta : Raja Grafindo Persada, 1985)

Soedarto, 2006, Kapita selekta Hukum Pidana, Alumni, Bandung

Surachmin dan Suhadi Cahaya. Strategi dan Teknik Korupsi Mengetahui Untuk Mencegah, Sinar Grafika. Jakarta, 2011.

\section{UNDANG-UNDANG}

Periksa Penjelasan Atas UU No. 31 Tahun 1999 Pasal 2 ayat (1).

Indonesia, Undang-Undang Nomor 31 Tahun 1999, Tentang Pemberantasan Tindak Pidana Korupsi, LN. No. 140 Tahun 1999, TLN No. 3874 Psl 2 ayat 1

Undang-Undang Nomor 20 Tahun 2001 tentang Pemberantasan Tindak Pidana Korupsi 
Penyalahgunaan Jabatan Wali Kota Bekasi Dalam Anggaran (Studi Kasus Putusan Nomor 2547 K/Pid.Sus/2011)

Undang-Undang Nomor 31 Tahun 1999 Tentang Pemberantasan Tindak Pidana Korupsi

Undang-Undang Nomor 20 Tahun 2001 Tentang Perubahan Atas UndangUndang Nomor 31 Tahun 1999 Tentang Pemberantasan Tindak Pidana Korupsi

Undang-Undang Republik Indonesia Nomor 46 Tahun 20092009 tentang Pengadilan Tindak Pidana Korupsi

\section{DATA INTERNET}

http://nasional.sindonews.com/read/201

2/09/11/18/671666/hukumsebagai-kaidahmoral-sosial, diakses pada tanggal 20 Maret 2013 Pukul 19.01 WIB

http://www.indonesiamedia.com/2011/0 2/02/banalisasi-korupsi/, diakses pada tanggal 26 Maret 2013, Pukul $21.00 \mathrm{WIB}$

http://definisipengertian.com/2012/penge rtian-definisi-korupsi-menurut-paraahli/, diakses pada tanggal 21 Maret 2013 pada pukul 16.00 WIB 